\title{
Changes in Radial Polyp Tissues of Acropora Longicyathus After Long-Term Exposure to Experimentally Elevated Nutrient Concentrations
}

OPEN ACCESS

Edited by:

Michael Sweet,

University of Derby, United Kingdom

Reviewed by:

Susana Enríquez,

Universidad Nacional Autónoma

de México, Mexico

Charles Alan Jacoby,

St. Johns River Water Management

District, United States

*Correspondence:

Daniel J. Bucher

daniel.bucher@scu.edu.au

Specialty section: This article was submitted to

Coral Reef Research,

a section of the journal Frontiers in Marine Science

Received: 30 May 2018 Accepted: 04 October 2018 Published: 23 October 2018

Citation:

Bucher DJ and Harrison PL (2018) Changes in Radial Polyp

Tissues of Acropora Longicyathus

After Long-Term Exposure to Experimentally Elevated Nutrient

Concentrations.

Front. Mar. Sci. 5:390.

doi: 10.3389/fmars.2018.00390

\author{
Daniel J. Bucher* and Peter L. Harrison
}

Marine Ecology Research Centre, School of Environmental Science and Engineering, Southern Cross University, Lismore, NSW, Australia

Coral tissues control growth and calcification processes that ultimately build coral reefs but relatively little information is available on the effects of nutrients on polyp tissues. The structure and organization of coral tissues were investigated using thin $(0.5-1 \mu \mathrm{m})$ sections of young $(<3$ months) radial polyps of the reef-building coral Acropora longicyathus that had been exposed to elevated concentrations of ammonium ('N') and/or phosphate ('P') in the ENCORE experiment at One Tree Island, southern Great Barrier Reef. Young polyps of N-treated corals had similar porosity but significantly decreased length of calicoblastic body wall per cross-section of the septotheca compared with controls. Other studies using older skeletons of the same corals found they were significantly less porous than controls and their branches had reduced extension rates and reduced lesion-healing ability, indicating that increased calcification occurred in the infilling process rather than during apical extension. The free body wall epidermal tissues of P-treated polyps were significantly thicker than corals in control conditions and their calyx walls had significantly greater length of calicoblastic body wall per cross-section despite similar porosity to controls. This suggests that phosphate stimulated tissue growth and apical calcification. Although other studies of the chlorophyll content of older tissue found it was significantly increased by phosphate treatments, more rapid extension of the branches kept Symbiodiniacean densities in the younger polyps similar to controls. We recorded a reduction in the density of mucous bodies in P-treated corals, which is potentially significant for the survival of corals in polluted water because of the important roles of mucus in facilitating removal of sediment from the coral surface and as a barrier to pathogen infection.

Keywords: ammonium, phosphate, porosity, mucus, coral tissue growth, symbiodiniaceae

\section{INTRODUCTION}

The role of nutrification (elevated concentrations of inorganic nitrogen and phospate) in the demise of coral reef communities has been the subject of much research, particularly following sudden shifts from coral-dominated to algal-dominated communities were documented for reefs including Kaneohe Bay, Hawaii (Smith et al., 1981), and elsewhere (Pastorok and Bilyard, 1985; 
Tomascik and Sander, 1987; Szmant, 2002). One mechanism by which nutrients were hypothesized to exert an effect was through direct negative impacts on coral physiology and health. However, while such impacts have been demonstrated in laboratory and field experiments, their magnitude is rarely sufficient to explain death or overgrowth of corals by other biota (Szmant, 2002).

One of the more ambitious experiments to manipulate nutrients in an intact coral reef system was the ENCORE project (Larkum and Steven, 1994). The project used 12 patch reefs in One Tree Reef Lagoon on the southern Great Barrier Reef. During 1995 concentrations of ammonium, phosphate, or a combination of both, were elevated by 10-20 times average lagoonal concentrations for the duration of each low tide. A number of studies of corals translocated into the ENCORE patch reefs have demonstrated significant impacts on reproduction and lipid levels (Ward, 1997; Ward and Harrison, 1997, 2000), photosynthetic processes (Takabayashi, 1996), growth and skeletal density (Hoegh-Guldberg et al., 1997; Bucher, 2000; Bucher and Harrison, 2000), and lesion-healing ability (Bucher, 2000) that support the hypothesis that nutrients may reduce coral resistance and/or resiliance to other stressors such as warm-water bleaching and physical damage. These results were subsequently questioned by Szmant (2002) who considered that the low abundance of acroporid corals in the micro-lagoons may have indicated that they did not provide a suitable natural habitat for these corals, and that nutrient effects on this genus may have been the result of some patch reefs being less suitable than others. However, the ENCORE design was replicated with three micro-lagoons for each treatment, and we had the opportunity to revisit the ENCORE reefs in November 2017 and noted that many of the transplanted colonies continue to thrive in the micro-lagoons some 20 years after the experiment. In particular, the smaller reefs to the western end of the lagoon are now almost impassable because of the high density of acroporid corals. We are therefore confident that the previous paucity of acroporid corals in these habitats was not due to poor environmental conditions. Moreover, the transplanted corals did not suffer from effects of crowding as the micro-lagoons have since supported a far higher density than was present during the experiment.

As a fast-growing, diverse taxon with a wide biogeographic distribution, the genus Acropora has been one of the groups on which nutrient studies have been focussed (Shantz and Burkepile, 2014). The gross anatomy of Acropora has been described by Constantz (1989), Veron (1986), and Wallace (1999). At the apex of each branch is a single apical polyp. Polyps that bud from the apical polyp, or which arise from the coenosarc, to line the sides of the branch, are termed radial polyps. The apical polyp of a rapidly extending branch, generally has very few microalgal dinoflagellates (family Symbiodiniaceae) in its tissues, is larger than the radial polyps around it, and its skeletal structure is extremely porous (Oliver, 1984; Fang et al., 1989).

The coelenteron of the axial polyp extends deep within the branch, occupying a canal along the central axis. The coelentera of the radial polyps also join the axial canal, and it has been suggested that excess photosynthate produced by the abundant symbiotic dinoflagellates in the radial polyps may be transported along the canal to the pale branch tip (Pearse and Muscatine, 1971; Oliver et al., 1983; Fang et al., 1989). Inorganic carbon produced by respiration of the deeper tissues may also be transported to the rapidly calcifying tip by ciliary currents, along with calcium ions. The unique anatomy of the Acropora colony therefore provides apical polyps with the supply of materials and energy they need for the rapid linear extension that is characteristic of the genus (Wallace, 1999).

The need for translocation of materials from deeper tissue implies that Symbiodiniaceae-free apical polyps probably require a critical mass of dinflagellate-rich tissue beneath them in order to maintain maximum extension rates. It therefore seems likely that a rapidly growing apical polyp may suppress initiation of new branches that would compete for translocated materials until there is a sufficient biomass of photosynthetic tissue to supply a second apical polyp. This may provide a simple model to explain the more frequent branching observed when colonies are transplanted into shallow water (e.g., Oliver et al., 1983), where the higher light levels may allow an apical polyp to be supplied by a smaller mass of dinflagellate-rich tissue. Supplies of molecules needed for organic growth could potentially have a similar effect. Suppression of branch initiation by the apical polyp would also explain the rapid initiation of new branches that occurs when an apical polyp is damaged. For this reason, we prefer the use of large transplanted fragments of colonies for growth experiments rather than juveniles, nubbins or branch tips that are commonly used (Takabayashi, 1996; Renegar and Riegl, 2005).

In 'bottlebrush' species such as Acropora longicyathus, there is a continuum of radial polyp shapes from sessile semicircular cups to elongate cylinders (Figure 1). The calices of all Acropora polyps are porous structures, consisting of skeletal elements that are parallel (septa) and perpendicular (synapticulae) to the polyp axis (Figure 1). Branches of the coelenteron fill the voids between these skeletal elements. For as long as they are in contact with the calicoblastic tissues of the coelenteron wall the skeletal elements will continue to thicken, presumably until the voids are no longer sufficiently interconnected to support the metabolic requirements of coral tissue. By this process, the basal portions

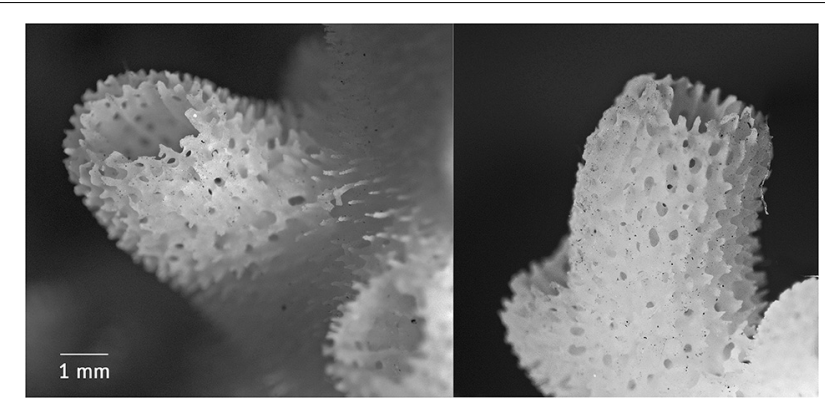

FIGURE 1 | Chemically bleached calices of individual radial polyps of Acropora longicyathus, showing the shape and the porous nature of the calyx walls (septotheca). 
of a large Acropora skeleton may become the least porous of any coral skeleton (Hughes, 1987).

The general features of the endoderm (gastrodermis), mesogloea and ectoderm (epidermis and calicoblastic tissue) of corals have been described by Barnes (1973), and the finer structure of the tissues of Acropora muricata have been described by Harrison (1980). Processes in living corals that result in changes in the balance between calcification and skeletal extension (Bucher, 2000; Bucher and Harrison, 2000), or which alter the ability of the coral to grow and maintain itself may be investigated further by examining the tissues of the polyps. Of particular importance are tissues associated with the response to irritants (mucous cells in the free body wall), skeleton production (the calicoblastic body wall) and the energy supply of the polyp (Symbiodiniacea).

Many studies have used light microscopy or transmission electron microscopy to examine coral tissues for descriptive or taxonomic purposes (see review by Chapman, 1974), or to examine the process of skeletogenesis (Johnston, 1977, 1979; Le Tissier, 1991). Others have described cellular changes associated with bleaching (Glynn et al., 1985) or infection by pathogens (Peters, 1984; Glynn et al., 1989). Very few studies have used histological techniques to examine subtle sub-lethal changes in parameters such as cell densities (other than Symbiodiniacean cells) or tissue thicknesses in a manipulative experimental setting, although Renegar et al. (2008) examined tissue and cell ultrastructure around areas of lesion repair in Montastrea cavernosa and Porites astreoides and identified differences in Symbiodiniaceae distribution and condition in regenerating tissue exposed to elevated nutrients, but this gives little guide to impacts on undamaged tissue.

Harrison et al. (1990) examined changes in Acropora muricata tissues when exposed to oil and oil dispersants. They described the sequence of stress responses of coral tissue to a range of exposure times, ranging from excessive mucus secretion, through symbiotic dinoflagellate loss, to thinning and eventual disintegration of the tissues. In this study, we compare histological cross-sections of recently formed radial polyps of A. longicyathus grown under conditions of elevated ammonium, phosphate, and a combination of both nutrients, with those grown in ambient conditions during the high-dose phase of the ENCORE experiment (Larkum and Steven, 1994; Koop et al., 2001).

\section{MATERIALS AND METHODS}

The experimental design of ENCORE has been described in detail elsewhere (e.g., Larkum and Steven, 1994) and is only briefly outlined here. Automated nutrient dispensing units were used to add concentrated nutrient solution to micro-lagoons within patch reefs in the main lagoon of One Tree Reef, Great Barrier Reef (Lat. $23^{\circ} 30^{\prime}$ Long. $152^{\circ} 06^{\prime}$ ). Three patch reefs remained unaltered as controls, three received ammonium ('N-only'), three received phosphate ('P-only'), and both nutrients were added to a further three patch reefs (' $\left.N+\mathrm{P}^{\prime}\right)$. Data presented here were collected during the 'high-dose' treatment period (see
Koop et al., 2001), when nutrient concentrations were elevated to approximately 20 times background levels $\left(20 \mu \mathrm{M} \mathrm{NH}_{4}{ }^{+}, 4 \mu \mathrm{M}\right.$ $\mathrm{PO}_{3}{ }^{2+}$ ) three times every low tide between January 1995 and February 1996.

Sixty colonies of the branching reef coral A. longicyathus from around the main lagoon were used to provide sub-colonies for transplant into the micro-lagoons. Five colonies were randomly assigned to each patch reef of which three were used for histological study. Transplanted sub-colonies were supported on racks made from PVC floor tiles raised on short $(\sim 10 \mathrm{~cm})$ lengths of PVC pipe. All data sets were analyzed with nested analyses of variance (ANOVA) and Tukey's honestly significant difference (HSD) multiple comparison of means. Results were initially analyzed using a two-way orthogonal model in which the treatments involving elevated ammonium (' $+\mathrm{N}$ ': $\mathrm{N}$-only and $\mathrm{N}+\mathrm{P})$ are compared with those with ambient ammonium ('- $\mathrm{N}$ ': Controls and P-only), P-only and $\mathrm{N}+\mathrm{P}\left({ }^{\prime}+\mathrm{P}\right.$ ') are compared with controls and N-only ('-P'), and the interaction between the two nutrient factors is assessed. Where there was a significant interaction between ammonium and phosphate treatments a model was applied in which each of the four treatments (Controls, N-only, P-only and $\mathrm{N}+\mathrm{P}$ ) were compared individually, with the emphasis placed on comparisons of elevated nutrient treatments with ambient controls. No significant interaction in the orthogonal model indicates that the effect of elevating one nutrient is independent of whether or not the other nutrient is also elevated and renders redundant the less-powerful linear model and post-hoc tests of multiple means.

Individual cylindrical radial polyps of A. longicyathus were removed with a knife blade from within $1.5-2 \mathrm{~cm}$ of the tip of the uppermost branches of each colony during June 1995. Linear extension rates (Bucher and Harrison, 2000) suggest that these polyps were no more than 5-6 months old, and had therefore been formed during the ENCORE high-dose nutrient treatment period (Koop et al., 2001).

All polyps were fixed immediately in cold $2.5 \%$ glutaraldehyde for 2-3 h in Millipore-filtered seawater, buffered with $0.1 \mathrm{M}$ sodium cacodylate, and adjusted to a pH of 7.2 (after Harrison, 1980). After three rinses in the cacodylate-buffered seawater, the polyps were stored in the final rinse for transport. The polyps were post-fixed for $1 \mathrm{~h}$ in $1 \% \mathrm{OsO}_{4}$ in cacodylate-buffered seawater, rinsed three time in cacodylate-buffered seawater, and stored refrigerated in the final rinse solution. Prior to embedding, the polyps were decalcified in ascorbic acid according to the method of Dietrich and Fontaine (1975) and were embedded in Spurr's resin (Spurr, 1969) for sectioning. Thin $(0.5-1.0 \mu \mathrm{m})$ sections were cut using glass knives on a Reichert OMU3 ultramicrotome. Sections were cut approximately $1 \mathrm{~mm}$ from the top of the calyx wall, perpendicular to the longitudinal axis. The sections were mounted on glass slides, stained with toluidine blue in borax (after Harrison, 1980) and photographed with a Panasonic CCTV digital video camera mounted on an Orion BM-LUX-2 compound microscope.

Digital images were captured using a 5 megapixal digital camera mounted on an Olympus compound microscope. The images were printed at a resolution of $144 \mathrm{dpi}$, giving a printed image size of $11 \mathrm{~cm} \times 8.5 \mathrm{~cm}$. All lengths and areas were 
measured from the printed images using a Wacom ArtZ II 12 " $\times 12$ " digitizing tablet. Scaling factors were obtained by photographing and digitizing $0.1 \mathrm{~mm}$ square haemocytometer grids at the same magnifications as the coral polyps. Images were obtained at three random locations on each of two polyps per colony. At each location three images were taken for analysis as shown in (Figure 2).

An image at $\mathrm{x} 40$ magnification enabled a cross-sectional view of a segment of the polyp from the outer body wall to near the inner margin of the mesenteries. The area of each image occupied by skeleton $\left(A_{\text {skeleton }}\right)$ and the total area of calyx wall $\left(A_{\text {total }}\right)$ in the image were digitized. Porosity of the calyx wall was then calculated as follows:

$$
\text { Porosity }=100^{*}\left(A_{\text {total }}-A_{\text {skeleton }}\right) / A_{\text {total }}
$$

On the x100 image, the number of Symbiodiniacean cells inside gastrodermal cells of the calicoblastic body wall were counted, and the length of calicoblastic body wall in the image was measured along the mesogloea.

At $\times 400$ magnification (Figure 3) the thickness of the epidermis and the total thickness of the outer body wall could be measured. The numbers of Symbiodiniacean cells in the gastrodermis of the free body wall, and the numbers of mucous bodies in the epidermis were counted and expressed as the number of mucus bodies per length of free body wall (measured along the mesogloea). We have followed the nomenclature of the symbiotic dinoflagellates recommended by LaJeunesse et al., 2018).

\section{RESULTS}

Tables 1, 2 summarize the means and results of analyses of variance for tissue variables measured from digital images of

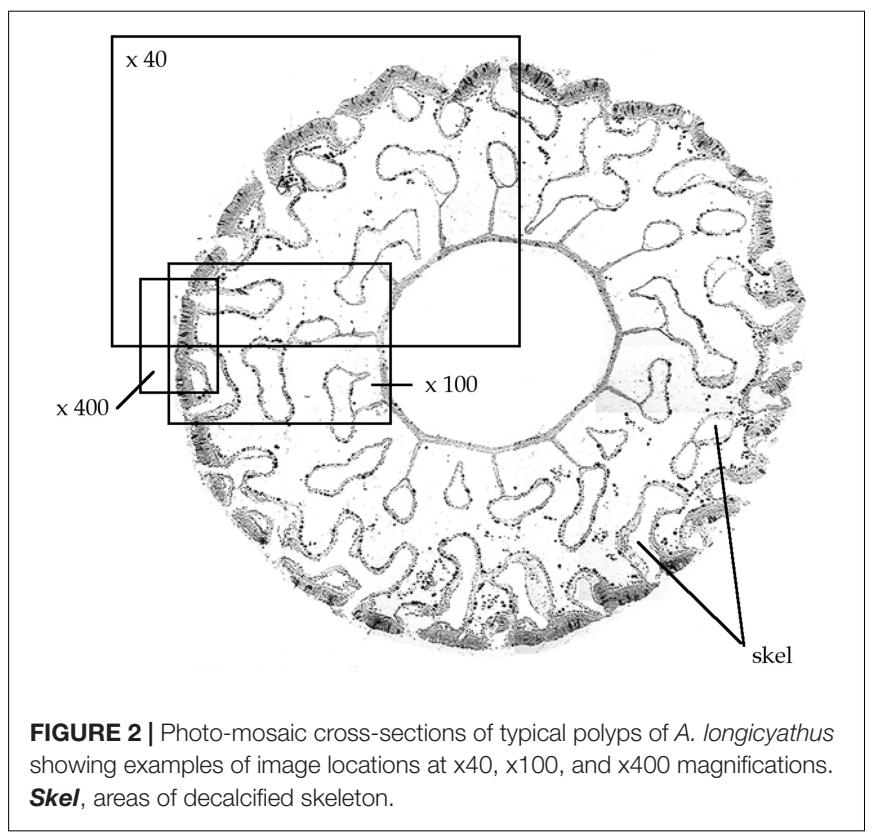

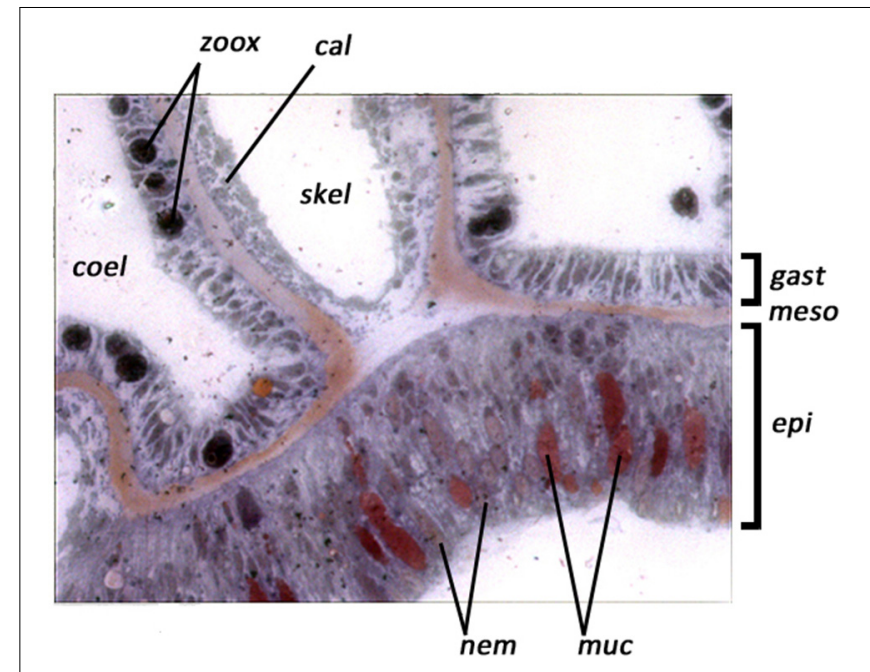

FIGURE 3 | Example of digital video images of a polyp cross section of Acropora longicyathus at x400 magnification, showing the tissue layers. Lining the coelenteron (coel) is the gastrodermis (gast) containing symbiotic dinoflagellates (zoox). The calicoblastic epithelium (cal) lines areas from which the skeleton has been decalcified (skel) and the epithelium (epi) of the free body wall contains mucous bodies (muc) and nematocysts (nem). Between the gastrodermis and epithelium lies the thin acellular mesogloea (meso).

A. longicyathus polyps. Three parameters produced significant treatment effects in the two-way orthogonal analyses of variance (Table 2). Elevated ammonium was associated with significantly increased Symbiodiniaceae densities in the calicoblastic body wall (' $C B W$ Zoox.') and a significantly reduced length of calicoblastic body wall ('CBW Length'). Elevated phosphate concentrations were associated with significantly reduced densities of mucous bodies in the free body wall. Significant $\mathrm{N} \times \mathrm{P}$ interaction terms occurred in three analyses ('Porosity,' 'FBW Zoox.' and 'FBW Width') in which the responses to the P-only treatment produced highest values but the $\mathrm{N}+\mathrm{P}$ treament produced values more similar to controls than any other nutrient treatment. Inter-reefal differences (within treatments) were detected in all parameters except 'FBW Width.' The dispersion of treatments in different patch reefs spread across the lagoon reduced the likelihood of reef differences being responsible for observed treatment effects. Significant colony effects (within reef) were detected in 'Porosity,' 'CBW Length,' 'Mucous Bodies', and 'FBW Width.' These significant effects were due to relatively small differences between colonies combined with low variation between polyps of the same colony.

Nested one-way analyses of variance and multiple comparisons of means (Tukey's HSD) showed that there were significant differences between treatments and control corals in porosity of the calyx wall ('Porosity'), the density of Symbiodiniaceae per unit length of calicoblastic body wall (' $C B W$ Zoox'), width of the free body wall (' $F B W$ Width' - due mostly to changes in ectodermal thickness), and the density of mucous bodies in the ectoderm of the free body wall ('Mucous Bodies'). P-only treated corals differed significantly from controls in regard to Porosity (increased relative to controls), FBW Width 
TABLE 1 | Summary of tissue variables of $A$. longicyathus measured in images of cross-sections of polyps.

\begin{tabular}{|c|c|c|c|c|}
\hline & Porosity (\%) & CBW Length (mm) & CBW Zoox $\left(\mathrm{mm}^{-1}\right)$ & FBW Zoox $\left(\mathrm{mm}^{-1}\right)$ \\
\hline$+\mathrm{N}(\mathrm{N}, \mathrm{N}+\mathrm{P})$ & $70.3 \pm 7.8(104)$ & $18.9 \pm 4.5(105)$ & $22.9 \pm 10.8(105)$ & $9.4 \pm 13.3(89)$ \\
\hline$+\mathrm{P}(\mathrm{P}, \mathrm{N}+\mathrm{P})$ & $70.9 \pm 7.4(96)$ & $20.8 \pm 4.6(102)$ & $20.5 \pm 8.7(101)$ & $9.6 \pm 10.3(83)$ \\
\hline Control & $69.3 \pm 7.3(54)$ & $21.7 \pm 4.6(54)$ & $18.6 \pm 8.3(54)$ & $7.3 \pm 12.3(49)$ \\
\hline N-only (N) & $71.3 \pm 8.0(53)$ & $18.5 \pm 4.6(54)$ & $23.6 \pm 12.1(54)$ & $11.9 \pm 15.7(46)$ \\
\hline$N+P$ & $68.3 \pm 7.3(51)$ & $19.4 \pm 4.4(51)$ & $22.2 \pm 9.2(51)$ & $6.7 \pm 9.6(43)$ \\
\hline All treatments & $67.4 \pm 7.5$ (203) & $20.4 \pm 4.7(210)$ & $20.8 \pm 9.3$ (209) & $9.6 \pm 12.5$ (178) \\
\hline
\end{tabular}

\begin{tabular}{lcc}
\hline & Mucous bodies $\left(\mathbf{m m}^{-\mathbf{1}} \mathbf{)}\right.$ & FBW width (cm on image) \\
\hline$-\mathrm{N}(\mathrm{C}, \mathrm{P})$ & $43.8 \pm 22.5(88)$ & $8.4 \pm 1.4(90)$ \\
$+\mathrm{N}(\mathrm{N}, \mathrm{N}+\mathrm{P})$ & $44.2 \pm 24.2(88)$ & $8.2 \pm 0.9(53)$ \\
$-\mathrm{P}(\mathrm{C}, \mathrm{N})$ & $50.8 \pm 23.9(93)$ & $8.0 \pm 1.1(68)$ \\
$+\mathrm{P}(\mathrm{P}, \mathrm{N}+\mathrm{P})$ & $36.4 \pm 20.2(83)$ & $8.6 \pm 1.3(75)$ \\
Control & $50.5 \pm 22.1(47)$ & $7.9 \pm 1.2(50)$ \\
$\mathrm{N}-$ only $(\mathrm{N})$ & $51.0 \pm 25.8(46)$ & $8.4 \pm 0.8(18)$ \\
P-only (P) & $36.0 \pm 20.6(41)$ & $9.1 \pm 1.4(40)$ \\
$\mathrm{N}+\mathrm{P}$ & $36.7 \pm 20.0(42)$ & $8.1 \pm 1.0(35)$ \\
All treatments & $44.0 \pm 23.3(176)$ & $8.4 \pm 1.2(143)$
\end{tabular}

The number of replicates (n) varies between treatments as some cross-sections were damaged during collection, fixation or mounting, preventing accurate measurement of lengths or areas. 'Porosity' is the \% of total polyp area in an image at $x 40$ magnification occupied by tissue or coelenteron. 'CBW Length' is the length of calicoblastic body wall in each image at x100 magnification. 'CBW Zoox.' is the density of symbiotic dinoflagellates per mm of calicoblastic body wall. 'FBW Zoox.' is the density of symbiotic dinoflagellates per mm of free body wall. 'Mucous Bodies' is the density of mucous bodies per mm of free body wall. 'FBW Width' is the total width of the free body wall.

TABLE 2 | Summary of analyses of variance for tissue variables of $A$. longicyathus measured in digital images of histological cross-sections of polyps collected in June 1995.

\begin{tabular}{llllll} 
Porosity (\%) & $\begin{array}{l}\text { CBW length } \\
(\mathrm{mm})\end{array}$ & $\begin{array}{l}\text { CBW zoox. } \\
(\text { cells } / \mathrm{mm})\end{array}$ & $\begin{array}{l}\text { FBW zoox. } \\
(\text { cells } / \mathrm{mm})\end{array}$ & $\begin{array}{l}\text { Mucous } \\
\text { bodies (per } \\
\text { mm of FBW) }\end{array}$ & $\begin{array}{l}\text { FBW width } \\
(\mathrm{cm} \text { on image) }\end{array}$ \\
\hline
\end{tabular}

\begin{tabular}{|c|c|c|c|c|c|c|c|c|c|c|c|}
\hline \multicolumn{12}{|c|}{ Orthogonal ANOVA model } \\
\hline \multicolumn{12}{|c|}{ Main effects } \\
\hline$+\mathrm{N}$ vs. $-\mathrm{N}$ & \multicolumn{2}{|l|}{$\ldots$} & \multicolumn{2}{|l|}{$\diamond \downarrow$} & \multicolumn{2}{|l|}{$\diamond \uparrow$} & $\ldots$ & \multicolumn{2}{|l|}{$\ldots$} & $\ldots$ & \\
\hline$+P$ vs. $-P$ & \multicolumn{2}{|l|}{$\cdots$} & $\ldots$ & & \multicolumn{2}{|l|}{$\cdots$} & $\ldots$ & \multicolumn{2}{|l|}{$\bullet \downarrow$} & $\ldots$ & \\
\hline \multicolumn{12}{|c|}{ Interactions } \\
\hline $\mathrm{NxP}$ & \multicolumn{2}{|l|}{$\diamond$} & $\ldots$ & & \multicolumn{2}{|l|}{$\cdots$} & $\diamond$ & \multicolumn{2}{|l|}{$\cdots$} & \multicolumn{2}{|l|}{$\diamond$} \\
\hline \multicolumn{12}{|c|}{ Nested terms } \\
\hline Polyp & \multicolumn{2}{|l|}{$\ldots$} & $\ldots$ & & \multicolumn{2}{|l|}{$\ldots$} & $\ldots$ & \multicolumn{2}{|l|}{$\ldots$} & \multicolumn{2}{|l|}{$\ldots$} \\
\hline \multicolumn{12}{|c|}{ Linear ANOVA model } \\
\hline \multirow[t]{3}{*}{ Highest } & $\mathrm{P}$ & ]$^{*}$ & $P$ & ] & $\mathrm{N}$ & ]$^{*}$ & $\mathrm{P}$ & $\mathrm{N}$ & ] & $\mathrm{P}$ & ] * \\
\hline & $\mathrm{N}$ & ] ] & & ] ] & $N+P$ & ] ] & $\mathrm{N}$ & & ] & $\mathrm{N}$ & ] ] \\
\hline & $\mathrm{C}$ & ] & $\mathrm{N}+\mathrm{P}]$ & ] ] & $\mathrm{P}$ & ] ] & C & $N+P$ & ]$^{*}$ & $N+P$ & ] \\
\hline lowest & $N+P$ & ] & $\mathrm{N}$ & ] & & ] & $\mathrm{N}+\mathrm{P}$ & $\mathrm{P}$ & ]* & C & ] \\
\hline
\end{tabular}

In the results of the orthogonal model indicates significant effects at $p<0.05$ and arrows indicate the direction of the effects of elevated ammonium ( $+N)$ or phosphate $(+P)$ compared with ambient concentrations $(-N$ or $-P)$. In the results of the linear ANOVA model, bars link treatment means that were not significantly different (Tukeys HSD test, $p<0.05)$ and * emphasizes treatments that were significantly different from controls.

(increased relative to controls) and Mucous Bodies (decreased relative to controls). The $\mathrm{N}$-only treatment differed significantly from controls in regard to ' $C B W$ Zoox.' (increased relative to controls) and had significantly lower ' $C B W$ Length' relative to P-only treated corals, but neither differed significantly from controls. The combined $(\mathrm{N}+\mathrm{P})$ treatment differed from controls only in regard to the reduced density of mucous bodies in the free body wall. 


\section{DISCUSSION}

Although elevated phosphate produced a significantly higher porosity of the calyx wall than controls, there was a significant interaction with ammonium because when the two were elevated simultaneously the result was similar to controls. A similar pattern occurred with free body wall thickness. This pattern indicates that the ratio of nutrients may be more important than the absolute concentrations in determining the outcomes in these parameters. It has been demonstrated that excess nitrogen can cause symptoms of phosphate starvation (D'Angelo and Wiedenmann, 2014), which can be offset when phosphate is simultaneously elevated. A similar effect of elevated phosphate alone may be possible but a mechanism has yet to be demonstrated.

The significant increase in porosity of the calyx wall in phosphate treatments reported here is consistent with the reduction of skeletal bulk density reported by Bucher and Harrison (2000) for whole branches of the same colonies in elevated phosphate. In elevated ammonium treatments, a high annual rate of colony calcification and low rates of linear extension (Bucher and Harrison, 2000) in large fragments of the same colonies led to reduced porosity of branches, but in the young polyps used in the present study (those near the growing tip of the branches), this was not evident and calyx wall porosities were similar to controls. The difference in response to elevated ammonium between the two studies may be because there were seasonal fluctuations of ambient nitrogen in the lagoon causing differences in the effect of elevated nitrogen on colony calcification (Bucher and Harrison, 2000). The young polyps in this study may only show the effects of the rapid summer-autumn growth prior to sampling when calcification was similar between nitrogen-treated corals and controls (Bucher and Harrison, 2000).

Symbiodiniaceae densities in recently formed polyps did not correspond with the appearance and chlorophyll content of the older branches of the same A. longicyathus colonies (Bucher and Harrison, 2000), in which the P-only treatment produced significantly higher values and controls the lowest. Low density and high variability of Symbiodiniaceae in histological sections of the free body wall of $A$. longicyathus meant that no nutrient treatment produced densities that were significantly different from controls in this study. Unlike the polyps of Acropora muricata (Harrison, 1980), the Symbiodiniaceae of recently formed polyps in A. longicyathus were more numerous in the gastrodermis of the calicoblastic body wall than in the free body wall. Ammonium-treated corals had significantly higher densities of Symbiodiniaceae in the calicoblastic body wall. However, significant differences in skeletal geometry between treatments meant that in ammonium-treated corals there was less area of calicoblastic body wall per volume of calyx wall. This difference offset the higher density of Symbiodiniaceae and produced almost identical counts per cross-sectional area of the calyx wall in all treatments. While exposure to elevated inorganic nitrogen, resulting in phosphate starvation, can increase physiological symptoms of high-light and high-temperature stress in the coral-Symbiodiniaceae symbiont, which can potentially lead to increased susceptibility to bleaching and mortality (Wiedenmann et al., 2013; Higuchi et al., 2015), the effect would be further exacerbated by the nitrogen-exposed corals having less tissue to house the population of symbiotic algae.

There was a significant increase in total free body wall thickness in elevated phosphate treatments, suggesting a greater amount of tissue per surface area of the colony. In high-light, oligotrophic conditions Symbiodiniaceae produce excess organic carbon compounds that they cannot use for growth because of a shortage of either nitrogen or phosphorus (Dubinsky and Jokiel, 1994). These energy-rich compounds are translocated to the host coral to fuel respiration of the animal tissue. The more photosynthate available to the coral, the more tissue it can support. However, to make more tissue the coral needs compounds containing nitrogen and phosphate. The animal tissue cannot assimilate inorganic nutrients, so it must obtain them as organic compounds such as dissolved amino acids, or living or dead particulate matter (Anthony, 2000). In nutrientenriched waters the symbiotic algae are apparently able to utilize a greater proportion of the photosynthate for their own growth and reproduction, leaving a smaller proportion to be translocated to the coral (Dubinsky and Jokiel, 1994). In some circumstances, the lower rate of translocation per algal cell can be compensated for by higher Symbiodiniacean densities (McGuire and Szmant, 1997), although this is not always the case (Scheufen et al., 2017). In the field conditions of this experiment, the higher rates of tissue production generally corresponded with higher Symbiodiniaceae densities.

If sufficient organic matter is available in the water column (as prey items, dissolved or particulate matter), then heterotrophic uptake may allow the coral to make use of any increased translocation of photosynthate for increased production of animal biomass (Muscatine et al., 1989). Growth of coral tissue could therefore increase when the concentration of the limiting nutrient is elevated, possibly after an initial depression of growth during the phase of rapid increase in the Symbiodiniaceae population. Porites furcata exposed to elevated nutrients from resident fish schools had significantly more tissue per unit surface area than colonies without fish schools (Muscatine et al., 1985). No significant differences in the ratio of tissue weight:skeletal weight were observed in Stylophora pistillata in the ENCORE project (Hoegh-Guldberg et al., 1997), although an examination of the three data sets presented in that paper suggests a possible increase in this ratio in the phosphate-only treatment over time, relative to the other three treatments. In the present study, increased tissue thickness of the free body wall in the phosphate treatment is a possible indication of greater tissue production. Ward (1997) demonstrated that the same colonies of $A$. longicyathus used in this experiment from the ENCORE phosphate treatments also had significantly higher concentrations of lipids than corals at ambient phosphate concentrations, suggesting that the phosphate-treated corals had higher energy reserves to support growth, metabolic activity and reproduction (Ward and Harrison, 2000). Increased tissue production requires construction of new skeletal structures to support the new tissue. Conversely, new skeletal elements require new tissue to cover them, whereas infilling of existing structures 
reduces the space available for living tissue. Significantly higher skeletal linear extension and slightly faster growth in colony volume of fragments of the same coral colonies used in this study (Bucher, 2000; Bucher and Harrison, 2000), together with greater skeletal porosity in the phosphate treatment support the conclusion of faster coral tissue production.

The reduction of mucous bodies in phosphate-treated corals is a potentially important finding from the present study because it may indicate a mechanism for synergistic effects of sediment, pathogens and nutrients and may have resulted from either increased frequency of mucus release or decreased rates of production. One use of mucus is to slough away sediment which settles on the coral surface (Stafford-Smith, 1993; Humanes et al., 2017). A coral may be able to remove sediment when in nutrient-poor water or it may survive high nutrients in otherwise clear water. However, a coral may not be able to deal with a combination of sediment and nutrients if nutrients reduce the coral's ability to remove the sediment. Mucus production has been suggested as a means by which the coral releases carbon-rich organic matter that has been translocated by symbiotic dinoflagellates in excess of the respiratory needs of the coral (Crossland et al., 1980). If elevated phosphate allowed for a greater proportion of photosynthate to be directed toward growth of algal and coral biomass, it would leave less excess carbon to be secreted as mucus. Alternatively, the higher phosphate concentration may have acted as an irritant to the coral tissue, triggering mucus release more often than in controls. Either process would have resulted in a reduction of mucous bodies within the tissue. Mucus may also act as a barrier to pathogenic infection. Bruno et al. (2003) and Vega Thurber et al. (2014) have shown that corals in areas with artificially elevated nutrients had a higher incidence of disease than corals from control reef areas, although whether this was due to direct physiological impacts on the coral animal or alterations to the

\section{REFERENCES}

Anthony, K. R. N. (2000). Enhanced particle-feeding capacity of corals on turbid reefs Great Barrier Reef, Australia. Coral Reefs 19, 59-67. doi: 10.1007/ s003380050227

Barnes, D. J. (1973). Growth in colonial scleractinians. Bull. Mar. Sci. 23, 280-298.

Bruno, J. F., Petes, L. E., Harvell, C. D., and Hettinger, A. (2003). Nutrient enrichment can increase the severity of coral diseases. Ecol. Lett. 6, 1056-1061. doi: $10.1111 /$ gcb. 12450

Bucher, D. J. (2000). The effects of Experimentally Elevated Nutrient Concentrations on Growth Rate, Skeletal Architecture and Soft Tissue Morphology of Acroporid Corals (Scleractinia: Acroporidae). Ph.D. thesis: Southern Cross University, Lismore, NSW.

Bucher, D. J., and Harrison, P. L. (2000). "Growth responses of the reef coral Acropora longicyathus to elevated inorganic nutrients: do responses to nutrients vary among taxa," in Proceedings of the 9th International Coral Reef Symposium, Bali Indonesia 23-27 Oct. 2000, eds M. K. Moosa, S. Soemodihardjo, A. Soegiarto, K. Romimohtarto, and A. Nontji (Wellington: Ministry for the Environment)), 443-448.

Chapman, G. (1974). "Cnidarian histology," in Coelenterate Biology, eds L. Muscatine and H. M. Lenhoff (New York): Academic Press), 1-92.

Constantz, B. R. (1989). "Skeletal organisation in Caribbean Acropora spp. (Lamarck)," in Origin, Evolution and Modern Aspects of Biomineralization in Plants and Animals, ed. R. E. Crick (New York: Plenum Press), 175-199. composition of the microbiome or a combination of both is not known.

The changes in the tissues of A. longicyathus revealed in this study indicate further mechanisms by which superficially healthy corals exposed to elevated ammonium or phosphate may be more sensitive to other environmental impacts. When nutrients remain the limiting factor in coral physiology, the ratio of nutrients may be more important than the absolute concentration for some symptoms of nutrient stress, but for others, such as reduction of mucous bodies in the presence of elevated phosphate or altered skeletal architecture in elevated nitrogen, the effects are independent of the presence of other nutrients.

\section{AUTHOR CONTRIBUTIONS}

$\mathrm{PH}$ conceived of the research idea and obtained initial funding. $\mathrm{DB}$ and $\mathrm{PH}$ equally shared in the experimental design and writing of this manuscript. DB conducted the primary field and laboratory work and statistical analyses, and $\mathrm{PH}$ contributed to field and laboratory work.

\section{FUNDING}

The field work for this study was funded by a grant from the Great Barrier Reef Marine Park Authority through the ENCORE program to $\mathrm{PH}$, and several internal research grants from Southern Cross University to DB and PH.

\section{ACKNOWLEDGMENTS}

The two reviewers provided helpful comments that improved the final manuscript.

Crossland, C. J., Barnes, D. J., Cox, T., and Devereux, M. (1980). Compartmentation and turnover of organic carbon in the staghorn coral Acropora formosa. Mar. Biol. 59, 181-187. doi: 10.1007/BF003 96866

D'Angelo, C., and Wiedenmann, J. (2014). Impacts of nutrient enrichment on coral reefs: new persprctives and implications for coastal management and reef survival. Curr. Opin. Environ. Sustain. 7, 82-93. doi: 10.1016/j.cosust.2013.11.029

Dietrich, H. F., and Fontaine, A. R. (1975). A decalcification method for ultrastructure of echinoderm tissues. Stain Technol. 50, 351-354. doi: 10.3109/ 10520297509117086

Dubinsky, Z., and Jokiel, P. L. (1994). Ratio of energy and nutrient fluxes regulates symbiosis between zooxanthellae and corals. Pac. Sci. 48, 313-324.

Fang, L., Chen, Y., and Chen, C. (1989). Why does the white tip of stony coral grow so fast without zooxanthellae? Mar. Biol. 103, 359-363. doi: 10.1007/ BF00397270

Glynn, P. W., Peters, E. C., and Muscatine, L. (1985). Coral tissue microstructure and necrosis - relation to catastrophic coral mortality in Panama. Dis. Aquat. Organ. 1, 29-37. doi: 10.3354/dao001029

Glynn, P. W., Szmant, A. M., Corcoran, E., and Cofer-Shabica, S. V. (1989). Condition of coral reef cnidarians from the northern Florida reef tract: pesticides, heavy metals and histopathological examination. Mar. Pollut. Bull. 20, 568-576. doi: 10.1016/0025-326X(89)90359-7 
Harrison, P. L. (1980). The Fine Structure of Acropora formosa (Dana, 1846) (Scleractinia: Anthozoa). B.Sc.Hons. thesis: James Cook University, Douglas QLD.

Harrison, P. L., Collins, J. C., Alexander, C. G., and Harrison, B. A. (1990). "The effects of fuel oil and dispersant on the tissues of a staghorn coral Acropora formosa: a pilot study," in Proceedings of the 2nd Workshop on the Role of Scientific Support Co-ordinator, eds I. Dutton and N. Holmes (Hastings: HMAS Cerberus), 51-61.

Higuchi, T., Yuyama, I., and Nakamura, T. (2015). The combined effects of nitrate with high temperature and high light intensity on coral bleaching and antioxidant enzyme activities. Reg. Stud. Mar. Sci. 2, 27-31. doi: 10.1016/j.rsma. 2015.08.012

Hoegh-Guldberg, O., Takabayashi, M., and Moreno, G. (1997). "The impact of long-term nutrient enrichment on coral calcification and growth," in Proceedings 8th International Coral Reef Symposium, Vol. 1, (Panama), 861-866.

Hughes, T. P. (1987). Skeletal density and growth form of corals. Mar. Ecol. Prog. Ser. 35, 259-266. doi: 10.3354/meps035259

Humanes, A., Fink, A., Willis, B. L., Fabricius, K. E., de Beerd, D., and Negrib, A. P. (2017). Effects of suspended sediments and nutrient enrichment on juvenile corals. Mar. Pollut. Bull. 125, 166-175. doi: 10.1016/j.marpolbul.2017.08.003

Johnston, I. S. (1977). "Aspects of the structure of a skeletal matrix, and the process of skeletogenesis in the reef coral Pocillopora damicornis," in Proceedings of the 3rd International Coral Reef Symposium, ed. D. L. Taylor (Miami: Rosenstiel School of Marine and Atmospheric Science), 447-453.

Johnston, I. S. (1979). The organisation of a structural organic matrix within the skeleton of a reef-building coral. Scann. Electron Microsc. 2, 421-431.

Koop, K., Hutchings, P. A., Hoegh-Guldberg, O., Booth, D., Brodie, J., Bucher, D., et al. (2001). ENCORE: the effect of nutrient enrichment on coral reefs: synthesis of results and management implications. Mar. Pollut. Bull. 42, 91-120. doi: 10.1016/S0025-326X(00)00181-8

LaJeunesse, T. C., Parkinson, J. E., Gabrielson, P. W., Jeong, H. J., Reimer, J. D., Voolstra, C. R., et al. (2018). Systematic revision of symbiodiniaceae highlights the antiquity and diversity of coral endosymbionts. Curr. Biol. 28, 1-11. doi: 10.1016/j.cub.2018.07.008

Larkum, A. W. D., and Steven, A. D. L. (1994). ENCORE: the effect of nutrient enrichment on coral reefs. 1. Experimental design and research programme. Mar. Pollut. Bull. 29, 112-120. doi: 10.1016/0025-326X(94)90434-0

Le Tissier, M. D. A. (1991). The nature of the skeleton and skeletogenic tissues in the Cnidaria. Hydrobiologia 21, 397-402. doi: 10.1007/BF00026492

McGuire, M. P., and Szmant, A. M. (1997). "Time course of physiological responses to NH4 + enrichment by a coral-zooxanthellae symbiosis," in Proceedings 8 th International Coral reef Symposium, Vol. 1, (Panama), 909-914.

Meyer, J. L., and Schultz, E. T. (1985). Tissue condition and growth rate of corals associated with schooling fish. Limnol. Oceanogr. 30, 157-166. doi: 10.4319/lo. 1985.30.1.0157

Muscatine, L., Falkowski, P. G., Dubinsky, Z., Cook, P. A., and McCloskey, L. R. (1989). The effect of external nutrient resources on the population dynamics of zooxanthellae in a reef coral. Proc. R. Soc. Lond. B 236, 311-324. doi: 10.1098/ rspb.1989.0025

Oliver, J. K. (1984). Intra-colony variation in the growth of Acropora formosa: extension rates and skeletal structure of white (zooxanthellae-free) and browntipped branches. Coral Reefs 3, 139-147. doi: 10.1007/BF00301958

Oliver, J. K., Chalker, B. E., and Dunlap, W. C. (1983). Bathymetric adaptations of reef-building corals at davies reef, Great Barrier Reef, Australia. I. Long-term growth responses of Acropora formosa (Dana 1846). J. Exp. Mar. Biol. Ecol. 73, 11-35. doi: 10.1016/0022-0981(83)90003-5

Pastorok, R. A., and Bilyard, G. R. (1985). Effects of sewage pollution on coral-reef communities. Mar. Ecol. Prog. Ser. 21, 175-189. doi: 10.1016/j.marpolbul.2013. 06.002

Pearse, V. B., and Muscatine, L. (1971). Role of symbiotic algae (zooxanthellae) in coral calcification. Biol. Bull. 141, 350-363. doi: 10.2307/1540123

Peters, E. C. (1984). A survey of cellular reactions to environmental stress and disease in Caribbean scleractinian corals. Helgolander Meersuntersungen 37, 113-137. doi: 10.1007/BF01989298
Renegar, D. A., and Riegl, B. M. (2005). Effect of nutrient enrichment and elevated $\mathrm{CO}_{2}$ partial pressure on growth rate of Atlantic scleractinian coral Acropora cervicornis. Marine Ecol. Progr. Ser. 293, 69-76. doi: 10.3354/meps293069

Renegar, D. A., Blackwelder, P., and Moulding, A. L. (2008). "Coral ultrastructural response to elevated $\mathrm{pCO} 2$ and nutrients during tissue repair and regeneration," in Proceedings of the 11th International Coral Reef Symposium, (Ft Lauderdale), 7-11.

Scheufen, T., Krämer, W. E., Iglesias-Prieto, R., and Enriquez, S. (2017). Seasonal variation modulates coral sensitivity to heat-stress and explains annual changes in coral productivity. Sci. Rep. 7:4937. doi: 10.1038/s49518-01704927-8

Shantz, A. A., and Burkepile, D. E. (2014). Context-dependent effects of nutrient loading on the coral-algal mutualism. Ecology 95, 1995-2005. doi: 10.1890/131407.1

Smith, S. V., Kimmerer, W. J., Laws, E. A., Brock, R. E., and Walsh, T. W. (1981). Kaneohe bay sewage diversion experiment: perspectives on ecosystem responses to nutritional perturbation. Pac. Sci. 35, 279-395.

Spurr, A. R. (1969). A low viscosity epoxy resin embedding medium for electron microscopy. J. Ultrastruct. Res. 26:31. doi: 10.1016/S0022-5320(69)90033-1

Stafford-Smith, M. G. (1993). Sediment-rejection efficiency of 22 species of Australian scleractinian corals. Mar. Biol. 115, 229-243. doi: 10.1007/ BF00346340

Szmant, A. M. (2002). Nutrient enrichment on coral reefs: is it a major cause of coral reef decline? Estuaries 25, 743-766. doi: 10.1007/BF02804903

Takabayashi, M. (1996). Impacts of in Situ Inorganic Nutrient Enrichment on the Scleractinian Corals, Stylophora pistillata and Pocillopora damicornis. M.Sc Thesis: University of Sydney: Sydney, NSW.

Tomascik, T., and Sander, F. (1987). Effects of eutrophication on reefbuilding corals. II. Structure of scleractinian coral communities on fringing reefs, Barbados, West Indies. Mar. Biol. 94, 53-75. doi: 10.1007/ BF00392900

Vega Thurber, R. L., Burkepile, D. E., Fuchs, C., Shantz, A. A., McMinds, R., and Zaneveld, J. R. (2014). Chronic nutrient enrichment increases prevalence and severity of coral disease and bleaching. Glob. Chang. Biol. 20, 544-554. doi: $10.1111 /$ gcb. 12450

Veron, J. E. N. (1986). Corals of Australia and the Indo-Pacific. Melbourne, VIC: Angus and Robertson.

Wallace, C. C. (1999). Staghorn Corals of the World. Melbourne,VIC: CSIRO Publishing.

Ward, S. (1997). The Effects of Elevated Nutrients on the Reproduction of Three Species of Acroporid Reef Corals. Ph.D. thesis: Southern Cross University, Lismore, NSW.

Ward, S., and Harrison, P. L. (1997). "The effects of elevated nutrient levels on settlement of coral larvae during the ENCORE experiment; Great Barrier Reef, Australia," in Proceedings of the 8th International Coral Reef Symposium, Vol. 1, (Panama), 891-896.

Ward, S., and Harrison, P. L. (2000). Changes in gametogenesis and fecundity of acroporid corals that were exposed to elevated nitrogen and phosphorus during the ENCORE experiment. J. Exp. Mar. Biol. Ecol. 246, 179-221. doi: $10.1016 /$ S0022-0981(99)00182-3

Wiedenmann, J. D., Angelo, C., Smith, E. G., Hunt, A. N., Legiret, F., Postle, A. D., et al. (2013). Nutrient enrichment can increase the susceptibility of reef corals to bleaching. Nat. Clim. Chang. 3, 160-164. doi: 10.1038/nclimate1661

Conflict of Interest Statement: The authors declare that the research was conducted in the absence of any commercial or financial relationships that could be construed as a potential conflict of interest.

Copyright $(\odot 2018$ Bucher and Harrison. This is an open-access article distributed under the terms of the Creative Commons Attribution License (CC BY). The use, distribution or reproduction in other forums is permitted, provided the original author(s) and the copyright owner(s) are credited and that the original publication in this journal is cited, in accordance with accepted academic practice. No use, distribution or reproduction is permitted which does not comply with these terms. 